\section{Phenology and Winter Hardiness of Cold- climate Grape Cultivars and Advanced Selections in lowa Climate}

\author{
James A. Schrader ${ }^{1}$, Diana R. Cochran ${ }^{2}$, Paul A. Domoto ${ }^{1}$, \\ and Gail R. Nonnecke ${ }^{1}$
}

ADDITIONAL INDEX WORDs. growing degree days, interspecific hybrids, stress resistance, viticulture, wine grapes

SuMmary. The popularity of grape (Vitis sp.) and wine production in the upper midwest region of the United States is increasing steadily. The development of several coldclimate, interspecific-hybrid grape cultivars (northern hybrids) since the 1980s has improved the probability of success for both new and established vineyards in this area of the country, but long-term data describing the performance of these cultivars in midwestern U.S. climates are needed to both aid growers in their choice of cultivars and to provide them with information about factors important in their management. We characterized the long-term winterhardiness and annual phenology of 12 cold-climate northern hybrid grape cultivars (two established cultivars, five newer cultivars, and five advanced selections) grown in a randomized and replicated field plot in central Iowa, an area that offers a warm growing season and very cold dormant season for grape culture. The established cultivars included in the study were Frontenac and St. Croix. The newer cultivars evaluated were Arandell, Corot noir, La Crescent, Marquette, and Petit Ami, and the advanced selections were $M N 1189, M N 1200, M N 1220, M N 1235$, and $M N$ 1258. The grape trial was established in 2008, and vines were evaluated from 2011 through 2017 for annual timing of budbreak, bloom, veraison, and harvest, as well as winter survival of vines and primary buds. As a group, the northern hybrids in our trial showed good winterhardiness of vines but variable hardiness of primary buds across the six winters, which ranged from warmer than average to much colder than average. In Iowa climate, buds of northern hybrids were generally most vulnerable to cold temperature damage from late-winter (March) low-temperature events or from extreme midwinter low-temperature events. The bud hardiness of individual cultivars ranged from very hardy (Frontenac, Marquette, and MN 1235) to poor hardiness (Arandell, Corot noir, Petit Ami, and MN 1189), with all 12 cultivars showing good bud survival during Iowa winters that were warmer than average, but the less-hardy cultivars showing poor bud survival during winters that were colder than average. Evaluations of phenology revealed that heat accumulation measured in growing degree days with a threshold of $50^{\circ} \mathrm{F}$ was not a reliable index for predicting the timing of annual developmental stages for the cultivars we tested. Our results indicate that northern hybrids rely on other factors in addition to heat accumulation for guiding annual development, and that factors such as photoperiod likely have a strong influence on phenological timing during seasons with unusual weather patterns. We determined that none of the cultivars were vulnerable to cold temperature damage to fruit before harvest in Iowa's climate, but that three of the cultivars (Arandell, Marquette, and MN 1235) were highly vulnerable to shoot damage from spring freeze events, and four others (Corot noir, La Crescent, MN 1200, and MN 1220) were moderately vulnerable to cold damage to shoots in spring. An itemized summary of the relative hardiness, vulnerabilities, and timing of phenological stages of the 12 cultivars is provided to aid growers in selection and management of grape cultivars for Iowa climate. Based on hardiness and phenology, four of these cultivars (Frontenac, MN 1258, MN 1220, and MN 1200) have the lowest risk of issues related to cold temperatures.

S ince the 1980s, there has been consistent progress in breeding and selection of cold-hardy, disease-resistant grape cultivars that are adapted to the cool, humid climates of the eastern and central United States. Many of these cultivars are based on interspecific hybridization between European common grape (Vitis vinifera) and native grape species, such as riverbank grape (Vitis riparia) and fox grape
(Vitis labrusca) (Reisch et al., 2002; Smiley et al., 2016). These "northern hybrids," a term used for cold-climate interspecific grape hybrids, are bred with cold tolerance as one of their target attributes, and they are generally more cold tolerant than French-American hybrids, American cultivars based on fox grape, and cultivars of common grape (Minnesota Grape Growers Association, 2016). With several established cold-climate cultivars available and an increasing number of hardy selections being tested and released by plant breeders, the potential for expansion of the grape and wine industry in colder regions, such as the upper midwestern United States, is stronger than ever before (Bordelon, 2001), but long-term empirical data quantifying the performance of selections under the unique stresses of these regions will be needed to inform growers' choices of cultivars and to provide them with information about factors important in their management (Smiley et al., 2016).

Even with the arrival of the new cold-climate cultivars, production of grapes in the upper midwest poses greater risks than in warmer areas of the United States. The climate of the upper midwestern United States presents the widest extremes between summer and winter average temperatures of any region in the United States, with Minnesota, North Dakota, South Dakota, and Iowa showing the greatest differences (54.4, $54.4,50.4$, and $49.9^{\circ} \mathrm{F}$, respectively) between summer and winter average temperatures of the 50 states (Current Results Publishing, 2019a, $2019 b$ ). These four states also have the third, second, seventh, and 1lth lowest average winter temperatures, respectively, of the 50 states (Current Results Publishing, 2019b), and severity of winter can vary greatly from year to year (Andresen et al., 2012). The survival and performance of cultivars in colder regions depend on their overall cold tolerance, their annual phenology (timing of annual development and dormancy), and how well these traits match with area climate. Even if there is little risk of winter damage to trunks or canes, cold temperatures and their timing can greatly reduce cultivar productivity by damaging or killing primary

\begin{tabular}{llll}
\hline $\begin{array}{l}\text { Units } \\
\text { To convert U.S. to SI, } \\
\text { multiply by }\end{array}$ & U.S. unit & SI unit & $\begin{array}{l}\text { To convert SI to U.S., } \\
\text { multiply by }\end{array}$ \\
\hline 10 & $\%$ & $\mathrm{~g} \cdot \mathrm{L}^{-1}$ & 0.1 \\
0.3048 & $\mathrm{ft}$ & $\mathrm{m}$ & 3.2808 \\
$\left({ }^{\circ} \mathrm{F}-32\right) \div 1.8$ & ${ }^{\circ} \mathrm{F}$ & ${ }^{\circ} \mathrm{C}$ & $\left({ }^{\circ} \mathrm{C} \times 1.8\right)+32$
\end{tabular}


buds (Goffinet, 2004; Londo and Kovaleski, 2017; Moyer et al., 2011). Productivity of grape cultivars is also dependent on phenology of budbreak, bloom, veraison, and harvest (Minnesota Grape Growers Association, 2016). If a cultivar breaks bud too early, the developing shoots can be killed by a late freeze in spring, causing loss of fruit production for that season (Dami et al., 2005). If the growing season is too short for a particular cultivar, grapes can be damaged by cold temperatures before the fruit can mature completely, or vines may not acclimate sufficiently in the fall to avoid injury during the following winter (Dami et al., 2005; Minnesota Grape Growers Association, 2016).

We examined the winterhardiness and annual phenology of 12 northern hybrid grape cultivars in central Iowa. Weather in Iowa varies greatly throughout the year, with average summer extreme highs of $96.4^{\circ} \mathrm{F}$ and average winter extreme lows of $-14^{\circ} \mathrm{F}$ for our trial location. For central Iowa, the average date of the last spring frost (light freeze, 29 to $32{ }^{\circ} \mathrm{F}$ ) per year is $23 \mathrm{Apr}$., and the average date for the first autumn frost per year is 11 Oct. (Iowa State University, 2019). This provides a typical frost-free growing season of $169 \mathrm{~d}$, a season length that is considered risky for production of many French-

Received for publication 31 July 2019. Accepted for publication 11 Sept. 2019.

Published online 25 October 2019

${ }^{1}$ Department of Horticulture, Iowa State University, Ames, IA 50011

${ }^{2}$ Department of Plant Science and Landscape Architecture, University of Maryland, College Park, MD 20742

This research was supported in part by the U.S. Department of Agriculture/National Institute of Food and Agriculture NE-1020 project "Multi-State Evaluation of Winegrape Cultivars and Clones" and by Iowa State University.

We thank Nicholas Howell and the staff of the Iowa State University Horticulture Research Station for their assistance with management of the research plot, and we thank Ashly Senske and Marcus Jansen for their helpful critiques of the manuscript.

J.A.S. is an Agricultural Specialist.

D.R.C. is an Assistant Clinical Professor.

P.A.D. is Emeritus Professor

G.R.N. is Morrill Professor, University Professor.

D.R.C. is the corresponding author. E-mail: cochrand@ umd.edu.

This is an open access article distributed under the CC BY-NC-ND license (https://creativecommons.org/ licenses/by-nc-nd/4.0/).

https://doi.org/10.21273/HORTTECH04475-19
American hybrid grapes, which need from 150 to 180 frost-free days for successful production (Dami et al., 2005). For most grape cultivars, emerging shoots in spring and mature leaves in fall are not killed until temperatures drop below $28^{\circ} \mathrm{F}$ (Jones, 2015; Minnesota Grape Growers Association, 2016), a factor that can increase the safe period for growth and survival of grapes in some cold regions, but both the timing and severity of cold temperatures are important factors that affect the vulnerability of cultivars in a local climate (Dami et al., 2005). Survival and performance of some of the cultivars that we evaluated have been assessed in other regions (Bradshaw et al., 2018; Hatterman-Valenti et al., 2016), but ours is the first report characterizing their performance in Iowa (or areas of similar climate), and our trial contains cultivars not included in evaluations at other sites.

The cultivars evaluated in our study included 10 newer cultivars and advanced selections: seven from the University of Minnesota ColdHardy Grape Breeding Program (La Crescent, Marquette, MN 1189, MN $1200, \mathrm{MN} 1220, \mathrm{MN} 1235$, and MN 1258), two from the breeding program at Cornell University (Arandell and Corot noir), and one selected and patented by David MacGregor $\left(\right.$ Petit Ami $\left.{ }^{\mathrm{TM}}\right)$. Two established cultivars (Frontenac and St. Croix) were included in our study as controls. Our objectives were as follows: 1 ) to determine the potential of each cultivar to withstand long-term climatic stresses in Iowa, 2) to characterize the winterhardiness and annual phenology of each cultivar in Iowa's climate, 3 ) to determine potential vulnerabilities of each cultivar in Iowa's climate based on winterhardiness and phenology, and 4) to compare the winterhardiness and phenology of the cultivars to help determine which ones may be best suited for commercial production in Iowa and other areas with similar climate. Results from this trial will provide sciencebased information that will 1 ) aid in cultivar selection, 2) deliver insights concerning management requirements for cultivars, and 3) help in determining the potential of each cultivar for consistent grape production in Iowa and areas with similar climate. To simplify discussion, we have chosen to use the term "cultivar" as a general term to represent both the "cultivars" and "advanced selections" in this study, we use the term "northern hybrids" to represent the 12 cold-climate cultivars that we evaluated, and we use the term "winter" as a general term to represent the period from 1 Oct. to 31 Mar.

\section{Materials and methods}

Plant materials, location, AND MANAgEMENT. Nursery-grown vines of 'Arandell', 'Corot noir', 'Frontenac', 'La Crescent', 'Marquette', 'MN 1189', 'MN 1200', 'MN 1220', 'MN 1235', 'MN 1258', 'Petit Ami', and 'St. Croix' were received from Double A Vineyards, Inc. (Fredonia, NY) as part of the NE-1020 project titled "Multi-state Evaluation of Winegrape Cultivars and Clones." Vines were planted on 20 May 2008 (10 cultivars) and 13 May 2009 (two cultivars, Arandell and MN 1258) at the Iowa State University Horticulture Research Station near Gilbert, IA [lat. $42^{\circ} 6^{\prime} 27^{\prime \prime} \mathrm{N}$, long. $93^{\circ} 35^{\prime} 24^{\prime \prime} \mathrm{W}$; U.S. Department of Agriculture hardiness zone 5a (USDA, 2019)]. Vines were arranged in a randomized complete block design with three-vine panels replicated six times (18 vines per cultivar) and bordered by guard rows and end vines. Soil at the research plot was a well-drained Clarion loam (fine-loamy, mixed, superactive, mesic Type Hapludoll). Vines of experimental units were trained to a high cordon (single-curtain bilateral cordon), with the trellis wire $6 \mathrm{ft}$ above the ground, vine spacing of $8 \times 10 \mathrm{ft}$, and line posts spaced $24 \mathrm{ft}$ apart. Vines were pruned and managed according to the protocols described by Domoto (2014) and Minnesota Grape Growers Association (2016), including compensatory pruning following winters with significant bud injury.

Data collection. Cultivars were evaluated annually for winter survival of vines and primary buds, and for timing of four phenological stages: $50 \%$ budbreak, $50 \%$ bloom, $50 \%$ veraison, and harvest maturity. To quantify winter survival of vines, each vine was examined for the presence or absence of live shoots three times during the growing season following each winter. If live shoots were present on a vine in late spring, mid-summer, and early autumn (June, August, and September, 
respectively), the vine was scored as surviving the previous winter. To quantify winter survival of primary buds, vines were evaluated in late March of each year by collecting two canes per vine that originated from a previous year spur. Canes were held at room temperature $\left(70 \pm 1^{\circ} \mathrm{F}\right)$ for $48 \mathrm{~h}$ to allow oxidation to occur in damaged tissue, after which the first five buds on each cane were assessed by slicing buds in crosssection and visually examining the primary bud for presence of brown discoloration or necrosis, as illustrated by Moyer et al. (2011). Percentage bud survival was calculated for each vine by dividing the number of dead buds by the total number of buds assessed, multiplying by 100 , then subtracting the product from 100. Bud survival for each experimental unit was the mean for the three vines in each unit.

Timing of each phenological stage was recorded as the numerical day of the year (DOY) when each vine reached the measurement threshold for each stage. Vines were considered to have reached $50 \%$ budbreak when $50 \%$ of buds per vine had reached stage 4 of the Modified Eichhorn-Lorenz (Modified E-L) phenological scale (Dry and Coombe, 2004). Vines were considered to have reached $50 \%$ bloom when $50 \%$ of inflorescences per vine had reached Modified E-L stage 23 , and vines were considered to have reached $50 \%$ veraison when $50 \%$ of berries per vine had reached Modified E-L stage 35 (Eichhorn and Lorenz, 1977). Harvest maturity for each cultivar was determined by assays of soluble solids (SS), $\mathrm{pH}$, and titratable acidity (TA) performed on $>25$ berries sampled randomly and proportionally from the top, middle, and bottom of clusters. Samples were juiced with a benchtop juicer and pressed through cheesecloth. The SS content of grapes was determined by using a temperature-compensating refractometer (ATAGO, Bellevue, WA). Juice pH was measured with a $\mathrm{pH}$ meter (Orion 2-Star; Thermo Fisher Scientific, Waltham, MA), and a $5-\mathrm{mL}$ juice sample was used to quantify TA by titration with $0.1-\mathrm{N}$ sodium hydroxide $(\mathrm{NaOH})$ to an endpoint of $\mathrm{pH} 8.2$ (Iland, 2004). Cultivars were considered to be at harvest maturity when SS,
$\mathrm{pH}$, and TA met the parameters set by Dharmadhikari and Wilker (2001) for white (21\% to $22 \% \mathrm{SS}, 3.2-3.4 \mathrm{pH}, 7-$ $\left.9 \mathrm{~g} \cdot \mathrm{L}^{-1} \mathrm{TA}\right)$ and red table wines $(22 \%$ to $24 \% \mathrm{SS}, 3.3-3.5 \mathrm{pH}, 6-8 \mathrm{~g} \cdot \mathrm{L}^{-1} \mathrm{TA}$ ), with adjustments for 'Corot noir' and 'St. Croix' ( $\approx 18 \%$ SS), which did not attain the standard SS levels (data not presented).

The DOY result for each phenological stage of each vine was used in combination with weather data to calculate growing degree days at base $50{ }^{\circ} \mathrm{F}$ (GDD 50). The GDD 50 units were calculated by subtracting the threshold temperature of 50 ${ }^{\circ} \mathrm{F}$ from the mean hourly temperatures in ${ }^{\circ} \mathrm{F}$, dividing each hourly value by 24 , then adding the 24 hourly values together to obtain the daily value, a method selected based on the findings of $\mathrm{Gu}$ (2016), which demonstrated that calculating GDD from hourly data is more precise than calculating GDD from averages of daily minima and maxima. Unless otherwise indicated, values of GDD 50 in this study represent the cumulative heat units accrued starting with 1 Jan. of each year. Weather conditions for the research plot were monitored continuously on-site by using a weather station with a temperature and relative humidity probe (CS215-L; Campbell Scientific, Logan, UT) and a data logger (CR 1000; Campbell Scientific) that logged conditions every $15 \mathrm{~min}$. Data were accumulated and accessed through the Iowa Environmental Mesonet (Iowa State University, 2019), including data used to calculate the 100-year daily record low temperatures for the trial location. Air temperature means for climate analyses were calculated from hourly data.

Data Analysis. Means for measured parameters were quantified to characterize winterhardiness and phenology of northern hybrid cultivars in Iowa climate. Data were analyzed for main effects, interactions, and means separation across years and across cultivars by using statistical software (JMP Pro version 11.0.0; SAS Institute, Cary, NC). Means separation analyses were conducted by using TukeyKramer honestly significant difference model $(P \leq 0.05)$. Based on the elements of our experimental design, our percentage data met the definition of continuous data (Livingstone, 2009; Sahu, 2013) and were analyzed accordingly. Correlation and regression analyses of the relationships between minimum temperature and primary bud survival across years were performed by using the multivariate function and the fit $\mathrm{Y}$ by $\mathrm{X}$ function, respectively, of JMP Pro statistical software. For correlation analyses, Spearman's correlation was chosen over Pearson's correlation, because Spearman's correlation is not limited to analyses of linear relationships (Weaver et al., 2017), and there was no evidence to suggest that relationships between minimum temperatures and bud survival should be linear.

The ratings and summary of the relative hardiness, vulnerabilities, and timing of phenological stages of the 12 northern hybrid cultivars were assigned based on the comparison of individual cultivars to the other northern hybrids in the trial as well as the overall means across the cultivars. Therefore, the ratings are specific to our trial and should not be compared directly to ratings from other publications. Ratings of general bud hardiness were based on percentage survival of primary buds across winters and on percentage bud survival during the two coldest winters of the trial. Ratings for bud vulnerability during late winter were based on percentage survival of primary buds during years with extreme cold temperature events in late winter and on correlations between bud survival and minimum temperatures in March. Ratings for shoot vulnerability in spring were based on timing of budbreak and on the percentage survival of shoots after the cold temperature event on 11 Apr. 2012 (Domoto et al., 2013). Characterization ratings for timing of budbreak, bloom, veraison, and harvest were comparative ratings assigned to each cultivar relative to the timing for other cultivars and compared with the overall mean across cultivars. Iowa suitability rank was a relative ranking of the 12 cultivars based on how well their hardiness and phenology matches with Iowa climate.

\section{Results and discussion Winterhardiness in lowa climate}

Climate characteristics. The cultivars in our trial were exposed to 
a wide range of the winter conditions that are possible in Iowa's climate, including temperature events that were considered uncommon or extreme. Winter 2011-12, 2015-16, and 2016-17 were warmer than the average for central Iowa, and Winter 2013-14 was much colder than the average (Table 1). The coldest temperature during the 7-year trial was $-23.5^{\circ} \mathrm{F}$ recorded on $11 \mathrm{Feb} .2014$, a reading that set the 100 -year record low temperature for that DOY. Other 100-year record low temperatures for a DOY were recorded on 7 Oct. 2012 $\left(19.1^{\circ} \mathrm{F}\right), 3$ Mar. $2014\left(-16.7^{\circ} \mathrm{F}\right)$, and 27 Feb. $2015\left(-16.7^{\circ} \mathrm{F}\right)$. These temperature events are of particular interest because one represents a very cold midwinter low, another represents a very cold early-winter low, and two others represent very cold late-winter lows for central Iowa. The occurrence over the six winters of both typical and atypical temperatures (Table l) provided a robust set of conditions in which to evaluate the phenology and winterhardiness of grape cultivars for use in Iowa and other areas of similar climate.

Along with these low-temperature events, there were several other noteworthy weather trends that occurred during the six winters of the trial. By separating the temperature readings from each winter by month (monthly mean, minimum, and difference between the mean and minimum), we were able to compare the effects of winter temperatures and their timing on the vine and bud survival of cultivars. Although Winter 201314 had the coldest midwinter low temperature of the six winters and was the coldest winter overall (winter mean of $26.4{ }^{\circ} \mathrm{F}$ ), Winter 2012-13 had the lowest mean and minimum temperatures for the month of October (Table 1 ), potentially stressing vines before adequately acclimated for cold temperatures (Antivilo et al., 2018; Londo and Kovaleski, 2017; Schrader and Graves, 2003). Winter 2012-13 also had the coldest average temperature for March, but March temperatures were more uniform during Winter 2012-13 than they were for Winter 2013-14 and 2014-15, with Mar. 2013 showing a warmer minimum temperature and smaller difference between mean and minimum temperatures than did the other two winters ( $\mathrm{Ta}$ ble 1). Even with the large variation in the timing and severity of cold temperatures across the six winters, cumulative chilling hours were greater than $1000 \mathrm{~h}$ for each of the winters (Table 1 ), indicating that for most cultivars, ample chilling hours for overcoming endodormancy and

Table 1. Comparative summary measurements of air temperature for winter months during the trial of northern hybrid grape cultivars and advanced selections performed in central Iowa. Values were calculated from hourly data recorded by an on-site weather station from 1 Oct. through 31 Mar. of each year (2011-17).

\begin{tabular}{|c|c|c|c|c|c|c|c|}
\hline & \multicolumn{7}{|c|}{ Air temp $\left({ }^{\circ} \mathbf{F}\right)^{\mathrm{z}}$} \\
\hline & 2011-12 & 2012-13 & 2013-14 & 2014-15 & 2015-16 & 2016-17 & $\begin{array}{c}6-y r \\
\text { mean }\end{array}$ \\
\hline October & 53.6 & 48.7 & 50.0 & 51.1 & 53.1 & 55.9 & 52.1 \\
\hline November & 39.7 & 39.0 & 33.1 & 29.7 & 42.3 & 44.6 & 38.1 \\
\hline December & 30.0 & 26.4 & 17.1 & 28.6 & 32.7 & 23.9 & 26.5 \\
\hline March & 52.0 & 28.2 & 30.0 & 38.7 & 42.6 & 36.9 & 38.1 \\
\hline Full winter & 38.7 & 31.1 & 26.4 & 31.1 & 36.5 & 36.7 & 33.4 \\
\hline \multicolumn{8}{|l|}{ Monthly minimum } \\
\hline October & 23.2 & 19.1 & 24.8 & 26.6 & 30.4 & 27.9 & 25.3 \\
\hline November & 15.1 & 10.8 & -1.4 & -5.7 & 7.9 & 15.1 & 7.0 \\
\hline December & 4.8 & -2.2 & -18.4 & -3.3 & 5.4 & -17.3 & -5.2 \\
\hline Full winter & $-9.9(21 \text { Jan. })^{y}$ & -7.8 (1 Feb.) & -23.5 (11 Feb.) & -17.1 (5 Feb.) & -10.7 (17 Jan.) & -17.3 (18 Dec.) & -14.4 \\
\hline \multicolumn{8}{|c|}{ Difference between mean and minimum ${ }^{x}$} \\
\hline October & 30.4 & 28.4 & 25.2 & 24.5 & 22.7 & 28.1 & 26.6 \\
\hline November & 24.5 & 28.3 & 34.2 & 34.2 & 34.4 & 29.5 & 30.9 \\
\hline December & 25.2 & 28.6 & 35.5 & 31.9 & 27.4 & 41.2 & 31.6 \\
\hline January & 36.7 & 27.0 & 31.1 & 38.7 & 30.8 & 29.3 & 32.3 \\
\hline February & 27.5 & 31.5 & 35.6 & 31.9 & 31.1 & 27.0 & 30.8 \\
\hline March & 43.4 & 20.0 & 46.1 & 45.2 & 34.9 & 34.7 & 37.4 \\
\hline Full winter & 48.6 & 38.9 & 49.1 & 48.2 & 47.2 & 54.0 & 47.7 \\
\hline $\begin{array}{l}\text { Dormancy chilling } \\
\text { hours }^{w}\end{array}$ & 1372 & 1210 & 1054 & 1155 & 1355 & 1457 & 1267 \\
\hline
\end{tabular}


achieving uniform budbreak were met during all winters of the trial (Dokoozlian, 1999; Londo and Johnson, 2014).

HaRdiness RESULTS AND IMPLICATIONS. Winterhardiness of vines was generally good for all cultivars in our trial, but hardiness of primary buds varied across years and among the 12 northern hybrid cultivars. Vine survival was very high (100\%) for all cultivars except Arandell and Corot noir, which had 95\% vine survival (Table 2). These two cultivars each had $5 \%$ vine loss from cold temperature damage experienced before 2012, and no further vine mortality during the 6 years that vines were evaluated. In evaluations of primary buds at the end of winter, the northern hybrids as a group showed the highest percentage of primary bud survival in 2012 and 2013 (93.3\% and $96.4 \%$, respectively) and the lowest survival of primary buds in 2014 and $2015(62.1 \%$ and $67.4 \%$, respectively) (Table 2 ). These results are partially explained by the general winter conditions experienced during the preceding winters, with Winter 2011-12 being the warmest on average, Winter 2012-13 having the warmest winter minimum temperature, and Winter 2013-14 being the coldest of the six winters (Table 1).

By using Spearman's correlation analysis and the temperature data separated by month (monthly mean, minimum, and difference between the mean and minimum) across years, we quantified the strength and significance of relationships between primary bud survival and parameters of air temperatures and their timing from 1 Oct. through 31 Mar. of each year (Table 3 ). For the northern hybrids as a group, primary bud survival was most strongly correlated with March minimum temperature $(\rho=0.701, P<0.001)$, and the next highest correlation was shown for the relationship between bud survival and overall winter minimum temperature $(\rho=0.654, P<0.001)$ (Table 3$)$. There was only a weak correlation between October minimum temperature and bud survival $(\rho=-0.347$, $P=0.003$ ), and bud survival was generally correlated more strongly with monthly minimum temperatures than it was with monthly means or differences between means and minima for northern hybrids as a group (Table 3). Regression analysis of March and overall winter minima show that $27.3 \%$ of the variance in primary bud survival of northern hybrids can be attributed to minimum temperatures in March $\left(R^{2}=\right.$ $0.273, P<0.001$ ) and $24.7 \%$ of the variance can be attributed to the overall winter minimum temperature $\left(R^{2}=0.247, P<0.001\right)$. These results indicate that, in Iowa's climate, primary buds of northern hybrids are generally more vulnerable to low temperatures in late winter (March) than during any other time of the winter. Of the factors evaluated in our study, the overall winter minimum temperature was likely the second most important factor affecting bud survival of northern hybrids in Iowa climate, and primary buds were not generally vulnerable to low-temperature damage in early winter (October) (Table 3).

These conclusions are also supported when comparing weather data from the winter seasons of the trial that resulted in the highest and lowest bud survival. The winter with the highest primary bud survival for northern hybrids as a group [2012$13(96.4 \%$ survival)] was generally much warmer than the winter with the lowest bud survival [2013-14 (62.1\% survival)], but early in Winter 2012-13 (7 Oct. 2012) there was a cold temperature event that broke the 100-year record for low temperature on that day (Fig. 1A). Even though this temperature event $\left(19.1^{\circ} \mathrm{F}\right.$ on 7 Oct. 2012) was extremely cold for early October, it had little or no effect on primary bud survival of northern hybrids that season (Table 2). The winter with the lowest bud survival (2013-14) was the coldest of the trial and had extreme cold temperature events in midwinter and late winter $\left(-23.5{ }^{\circ} \mathrm{F}\right.$ on 11 Feb. and $-16.7^{\circ} \mathrm{F}$ on 3 Mar., respectively) that broke the 100 -year record low temperature for the days that they occurred (Fig. 1A). Results of bud survival recorded at the end of these winters were consistent with the conclusions made from correlation and regression analyses.

Table 2. Survival of vines and primary buds of cold-climate northern hybrid grape cultivars and advanced selections recorded after each of six winters in central Iowa.

\begin{tabular}{|c|c|c|c|c|c|c|c|c|}
\hline \multirow{2}{*}{$\begin{array}{l}\text { Cultivars and } \\
\text { selections }\end{array}$} & \multirow{2}{*}{$\begin{array}{l}\text { Vine survival (\%) } \\
\text { across all years }\end{array}$} & \multicolumn{7}{|c|}{ Primary bud survival (\%) } \\
\hline & & All 6 years & 2012 & 2013 & 2014 & 2015 & 2016 & 2017 \\
\hline 'Arandell' & $95 b^{z}$ & $57.6 \mathrm{c}$ & na & $95.0 \mathrm{abc}$ & $35.0 \mathrm{de}$ & $14.2 \mathrm{e}$ & $96.1 \mathrm{a}$ & $60.4 \mathrm{c}$ \\
\hline 'Frontenac' & $100 \mathrm{a}$ & $92.2 \mathrm{a}$ & $93.3 \mathrm{ab}$ & $100.0 \mathrm{a}$ & $91.1 \mathrm{a}$ & 86.9 a & $83.9 \mathrm{ab}$ & $97.8 \mathrm{a}$ \\
\hline 'La Crescent' & $100 \mathrm{a}$ & 88.9 a & $91.2 \mathrm{ab}$ & $100.0 \mathrm{a}$ & $77.2 \mathrm{ab}$ & $80.0 \mathrm{ab}$ & $90.6 \mathrm{ab}$ & $94.4 \mathrm{a}$ \\
\hline 'Marquette' & $100 \mathrm{a}$ & $90.3 \mathrm{a}$ & $91.6 \mathrm{ab}$ & $99.2 \mathrm{abc}$ & $83.9 \mathrm{ab}$ & $87.2 \mathrm{a}$ & $92.2 \mathrm{ab}$ & 87.8 a \\
\hline MN 1220 & $100 \mathrm{a}$ & 86.9 a & $92.7 \mathrm{ab}$ & $100.0 \mathrm{a}$ & $76.1 \mathrm{ab}$ & $76.7 \mathrm{bc}$ & $88.3 \mathrm{ab}$ & $87.8 \mathrm{a}$ \\
\hline MN 1235 & $100 \mathrm{a}$ & $91.4 \mathrm{a}$ & $98.0 \mathrm{a}$ & $99.5 \mathrm{ab}$ & $82.2 \mathrm{ab}$ & $91.7 \mathrm{a}$ & $83.9 \mathrm{ab}$ & $93.3 \mathrm{a}$ \\
\hline MN 1258 & $100 \mathrm{a}$ & 88.1 a & $100.0 \mathrm{a}$ & $99.0 \mathrm{abc}$ & $86.4 \mathrm{a}$ & $86.7 \mathrm{ab}$ & 76.7 b & $91.7 \mathrm{a}$ \\
\hline 'Petit Ami' & $100 \mathrm{a}$ & $67.5 \mathrm{bc}$ & $87.5 \mathrm{~b}$ & $92.6 \mathrm{c}$ & $68.3 \mathrm{bc}$ & $38.1 \mathrm{~cd}$ & $88.9 \mathrm{ab}$ & $40.6 \mathrm{~d}$ \\
\hline 'St. Croix' & $100 \mathrm{a}$ & $83.2 \mathrm{ab}$ & $95.0 \mathrm{ab}$ & $96.7 \mathrm{abc}$ & $57.2 \mathrm{~cd}$ & $63.1 \mathrm{c}$ & $94.4 \mathrm{a}$ & $92.8 \mathrm{a}$ \\
\hline
\end{tabular}

${ }^{\mathrm{z}}$ Means within a column followed by the same lowercase letter are not different according to Tukey-Kramer honestly significant difference test at $P \leq 0.05$ (n $=36$ for results across all 6 years, $\mathrm{n}=6$ for results within each year).

${ }^{\mathrm{y}}$ Means within the row followed by the same uppercase letter are not different according to Tukey-Kramer honestly significant difference test at $P \leq 0.05$ ( $\mathrm{n}=72$ ). 
Table 3. Correlation coefficients and significance for relationships between primary bud survival and parameters of air temperature during winter dormancy months for each northern hybrid grape cultivar or advanced selection and across the 12 cultivars and selections during the 7-year trial in central Iowa. Relationships were evaluated across years by using Spearman's correlation analysis.

\begin{tabular}{|c|c|c|c|c|c|c|}
\hline & 'Arandell' & 'Corot noir' & 'Frontenac' & 'La Crescent' & 'Marquette' & MN 1189 \\
\hline October & $0.028^{\mathrm{z}}(0.889)$ & $0.268(0.161)$ & $-0.042(0.808)$ & $0.046(0.791)$ & $-0.236(0.172)$ & $0.180(0.309)$ \\
\hline December & $0.340(0.077)$ & $0.528(0.003)$ & $-0.218(0.203)$ & $0.130(0.449)$ & $0.234(0.177)$ & $0.520(0.002)$ \\
\hline January & $-0.115(0.561)$ & $0.584(0.001)$ & $0.217(0.204)$ & $0.244(0.151)$ & $-0.001(0.996)$ & $0.286(0.102)$ \\
\hline February & $0.467(0.012)$ & $0.575(0.001)$ & $0.277(0.102)$ & $0.448(0.006)$ & $0.133(0.447)$ & $0.540(0.001)$ \\
\hline \multicolumn{7}{|c|}{ Monthly minimum } \\
\hline October & $0.198(0.313)$ & $-0.231(0.227)$ & $-0.325(0.053)$ & $-0.228(0.181)$ & $-0.214(0.218)$ & $0.035(0.846)$ \\
\hline November & $0.564(0.002)$ & $0.745(<0.001)$ & $0.389(0.019)$ & $0.525(0.001)$ & $0.197(0.258)$ & $0.497(0.003)$ \\
\hline December & $0.587(0.001)$ & $0.607(<0.001)$ & $-0.053(0.761)$ & $0.327(0.052)$ & $0.398(0.018)$ & $0.642(<0.001)$ \\
\hline \multicolumn{7}{|c|}{ Difference between mean and minimum } \\
\hline October & $0.077(0.697)$ & $0.506(0.005)$ & $0.449(0.006)$ & $0.401(0.015)$ & $0.161(0.357)$ & $0.179(0.311)$ \\
\hline November & $0.006(0.977)$ & $-0.502(0.001)$ & $-0.438(0.008)$ & $-0.440(0.013)$ & $-0.202(0.245)$ & $-0.216(0.219)$ \\
\hline December & $-0.491(0.008)$ & $-0.569(0.001)$ & $0.106(0.539)$ & $-0.207(0.225)$ & $-0.308(0.072)$ & $-0.397(0.020)$ \\
\hline January & $-0.692(<0.001)$ & $-0.201(0.296)$ & $-0.506(0.002)$ & $-0.570(<0.001)$ & $-0.430(0.010)$ & $-0.481(<0.001)$ \\
\hline February & $-0.467(0.012)$ & $-0.575(0.001)$ & $-0.277(0.102)$ & $-0.448(0.006)$ & $-0.133(0.447)$ & $-0.540(0.001)$ \\
\hline March & $-0.610(0.001)$ & $-0.499(0.006)$ & $-0.540(0.001)$ & $-0.696(<0.001)$ & $-0.530(0.001)$ & $-0.703(<0.001)$ \\
\hline Full winter & $-0.505(0.006)$ & $-0.329(0.082)$ & $-0.059(0.732)$ & $-0.276(0.104)$ & $-0.526(0.001)$ & $-0.418(0.014)$ \\
\hline
\end{tabular}

Winter 2014-15 was generally not as cold as Winter 2013-14, but primary bud survival for northern hybrids as a group was not greater in 2015 than it was in 2014 (Table 2). The likely explanation for these results can be resolved by comparing the daily minimum temperatures during these two winters (Fig. 1B). The first notable factor of the temperature profiles (Fig. 1B) is that both years had cold temperature events late in winter $\left(-16.7^{\circ} \mathrm{F}\right.$ on 3 Mar. 2014 and $-16.7^{\circ} \mathrm{F}$ on $27 \mathrm{Feb}$. 2015). The second important factor was the occurrence of two unseasonably warm periods during Winter 2014-15 (nearly all of December and again from mid- to late January), and each of these warm phases was followed by a quick return to cold temperatures (Fig. 1B). Based on the findings of Londo and Kovaleski (2017) that grape cultivars can deacclimate during periods of sustained warmer temperatures even in midwinter, it is possible that some of the cultivars lost a portion of their hardiness during the warm periods in
2014-15 and suffered damage to buds with the quick return of cold temperatures that followed each of these warm periods (Fig. 1B).

In results for individual cultivars, seven of the cultivars stood out as having the highest percentage of primary bud survival across the 6 years of evaluations. 'Frontenac', 'MN 1235', and 'Marquette' each averaged more than $90 \%$ bud survival across years, and 'La Crescent', 'MN 1258', 'MN 1220 ', and 'MN 1200' each averaged more than $85 \%$ survival of primary buds across the 6 years (Table 2). 'Frontenac', 'MN 1258', 'Marquette', and 'MN 1235' had very good bud survival through the coldest of the six winters (2013-14), with each showing more than $80 \%$ survival of primary buds after that winter and 'Frontenac' showing more than $90 \%$ survival. Although all 12 cultivars showed good bud survival during the mildest winters (2011-12, 2012-13, and 201516) of our trial, four of the cultivars (Arandell, Corot noir, MN 1189, and Petit Ami) had poor bud survival during at least two of the three colder winters (2013-14, 2014-15, and/or 2016-17), with bud survival below $41 \%$ and as low as $6.1 \%$ (Tables 1 and 2). 'St. Croix' was not as winter hardy as five of the newer cultivars during the two coldest winters (2013-14 and 2014-15), showing lower bud survival (57.2\% and $63.1 \%$, respectively) during these 2 years (Table 2 ).

As seen with the correlations for the northern hybrids as a group, nearly all of the individual cultivars showed a moderate to strong correlation between March minimum temperature and primary bud survival, as well as between the overall winter minimum temperature and bud survival (Table $3)$. Only two of the cultivars (MN 1220 and MN 1235) showed significant relationships between October minimum temperatures and primary bud survival, and these weak-to-moderate correlations $(\rho=-0.388, P=$ 0.020 and $\rho=-0.400, P=0.016$, respectively) were negative, suggesting that if they affected bud survival at all, it was most likely a failure of warmer October temperatures to prepare vines for colder temperatures later in the 
Table 3. (Continued) Correlation coefficients and significance for relationships between primary bud survival and parameters of air temperature during winter dormancy months for each northern hybrid grape cultivar or advanced selection and across the 12 cultivars and selections during the 7-year trial in central Iowa. Relationships were evaluated across years by using Spearman's correlation analysis.

\begin{tabular}{|c|c|c|c|c|c|c|}
\hline MN 1200 & MN 1220 & MN 1235 & MN 1258 & 'Petit Ami' & 'St. Croix' & Across cultivars \\
\hline \multicolumn{7}{|l|}{ Monthly mean } \\
\hline $0.316(0.061)$ & $-0.020(0.908)$ & $0.043(0.802)$ & $-0.132(0.488)$ & $-0.291(0.100)$ & $0.264(0.120)$ & $0.014(0.909)$ \\
\hline $0.331(0.049)$ & $0.357(0.032)$ & $0.196(0.252)$ & $0.053(0.780)$ & $0.156(0.386)$ & $0.601(<0.001)$ & $0.338(0.004)$ \\
\hline $0.410(0.013)$ & $0.179(0.296)$ & $0.183(0.285)$ & $0.230(0.222)$ & $0.392(0.024)$ & $0.328(0.051)$ & $0.251(0.035)$ \\
\hline $0.604(<0.001)$ & $0.298(0.077)$ & $0.458(0.005)$ & $0.244(0.193)$ & $-0.247(0.166)$ & $0.395(0.017)$ & $0.313(0.008)$ \\
\hline $0.555(<0.001)$ & $0.426(0.010)$ & $0.383(0.021)$ & $0.188(0.321)$ & $0.035(0.846)$ & $0.650(<0.001)$ & $0.419(<0.001)$ \\
\hline \multicolumn{7}{|l|}{ Monthly minimum } \\
\hline$-0.156(0.362)$ & -0 . & $-0.400(0.016)$ & $-0.2298(0.222)$ & -0.2 & -0.14 & $03)$ \\
\hline $0.544(0.001)$ & $0.587(<0.001)$ & $0.505(0.002)$ & $0.243(0.196)$ & $0.309(0.080)$ & $0.704(<0.001)$ & $0.574(<0.001)$ \\
\hline $0.467(0.004)$ & $0.396(0.017)$ & $0.315(0.061)$ & $0.346(0.061)$ & $0.603(<0.001)$ & $0.514(0.001)$ & $0.445(<0.001)$ \\
\hline $0.551(0.001)$ & $0.639(<0.001)$ & $0.555(<0.001)$ & $0.312(0.094)$ & $0.071(0.696)$ & $0.709(<0.001)$ & $0.565(<0.001)$ \\
\hline
\end{tabular}

Difference between mean and minimum

\begin{tabular}{llllllr}
$0.416(0.012)$ & $0.526(0.001)$ & $0.535(0.001)$ & $0.299(0.109)$ & $0.165(0.360)$ & $0.445(0.007)$ & $0.497(<0.001)$ \\
$-0.541(0.001)$ & $-0.537(0.001)$ & $-0.611(<0.001)$ & $-0.403(0.027)$ & $-0.051(0.780)$ & $-0.461(0.005)$ & $-0.514(<0.001)$ \\
$-0.399(0.016)$ & $-0.340(0.043)$ & $-0.305(0.070)$ & $-0.292(0.118)$ & $-0.702(<0.001)$ & $-0.382(0.022)$ & $-0.406(<0.001)$ \\
$-0.109(0.527)$ & $-0.535(0.001)$ & $-0.278(0.101)$ & $-0.265(0.158)$ & $-0.324(0.066)$ & $-0.507(0.002)$ & $-0.436(<0.001)$ \\
$-0.555(<0.001)$ & $-0.426(0.010)$ & $-0.383(0.021)$ & $-0.188(0.321)$ & $-0.035(0.846)$ & $-0.650(<0.001)$ & $-0.419(<0.001)$ \\
$-0.468(0.004)$ & $-0.696(<0.001)$ & $-0.530(0.001)$ & $-0.414(0.023)$ & $-0.282(0.113)$ & $-0.711(<0.001)$ & $-0.611(<0.001)$ \\
$-0.188(0.272)$ & $-0.357(0.033)$ & $-0.265(0.118)$ & $-0.358(0.052)$ & $-0.597(<0.001)$ & $-0.234(0.169)$ & $-0.348(0.003)$ \\
\hline
\end{tabular}

${ }^{{ }^{2}}$ Numbers without parentheses $=$ Spearman's correlation coefficient $(\rho)$. Numbers within parentheses $=(P>\rho)$, the indicator of significance for the correlation $(n=36)$.

winter (Table 3). Therefore, as we saw with results for northern hybrids as a group, we also conclude that none of the individual cultivars are vulnerable to cold temperature damage to buds in early winter (October) in Iowa's climate.

The correlation between March minimum temperature and bud survival was strongest for two of the cultivars that showed poor winter bud hardiness during our trial [Arandell and Corot noir $(\rho=0.780$ and 0.826 , respectively)], and the cultivar with the highest bud hardiness across years (Frontenac) was the only cultivar that showed no significant correlation between March minimum temperature and bud survival $(\rho=$ $0.2959, P=0.0798$ ), as well as no significant correlation between overall winter minimum temperature and bud survival $(\rho=0.2837, P=$ 0.0935 ). Of the four cultivars that had the poorest winter bud hardiness of the trial (Arandell, Corot noir, MN 1189, and Petit Ami), Petit Ami was the only one that appeared to be more vulnerable to damage by overall winter minimum temperature than to
March minimum temperature $(\rho=$ 0.6318 and 0.6222 , respectively). This characteristic of 'Petite Ami' could be partially explained by the lack of correlation between its bud survival and the difference between mean and minimum temperatures for March, a result that may reflect slower deacclimation than some cultivars during late winter warm periods ( $\mathrm{Ta}$ ble 3). Marquette and MN 1258 were the only other cultivars that showed a stronger correlation between overall winter minimum temperature and bud survival than between March minimum temperature and bud survival (Table 3). However, the consistently high percentages of bud survival for these two cultivars across all years indicate that they are sufficiently hardy to withstand cold winters in Iowa without significant bud mortality (Table 2 ).

The cultivar with the third strongest correlation between March minimum temperature and bud survival was St. Croix, a result that may help explain the lower bud survival of this established cultivar during Winter 2013-14 and 2014-15, winters that each had record low-temperature events in late winter (Tables 2 and 3 , Fig. 1B). Although 'St. Croix' also appears to be somewhat vulnerable to low temperature damage to buds during midwinter in Iowa climate $(\rho=0.709, P<0.001$ and $\rho=$ $0.606, P<0.001$ for correlations with January minimum and overall winter minimum, respectively), it had its lowest bud survival during years with late-winter cold temperature events, and it had good bud survival $(92.8 \%)$ during Winter 2016-17, which had a midwinter low temperature $(-17.3$ ${ }^{\circ} \mathrm{F}$ on $18 \mathrm{Dec}$.) that was similar to minima during the other 2 years but without a late-winter cold event ( $\mathrm{Ta}$ bles 1-3). Regression analysis also supports the conclusion that 'St. Croix' is more vulnerable to bud damage in late winter than in midwinter, with $78.5 \%$ of the variance in primary bud survival of 'St. Croix' being attributable to minimum temperatures in $\operatorname{March}\left(R^{2}=0.785, P<0.001\right)$ and $58.4 \%$ of the variance being attributable to the overall winter minimum $\left(R^{2}=0.584, P<0.001\right)$. 

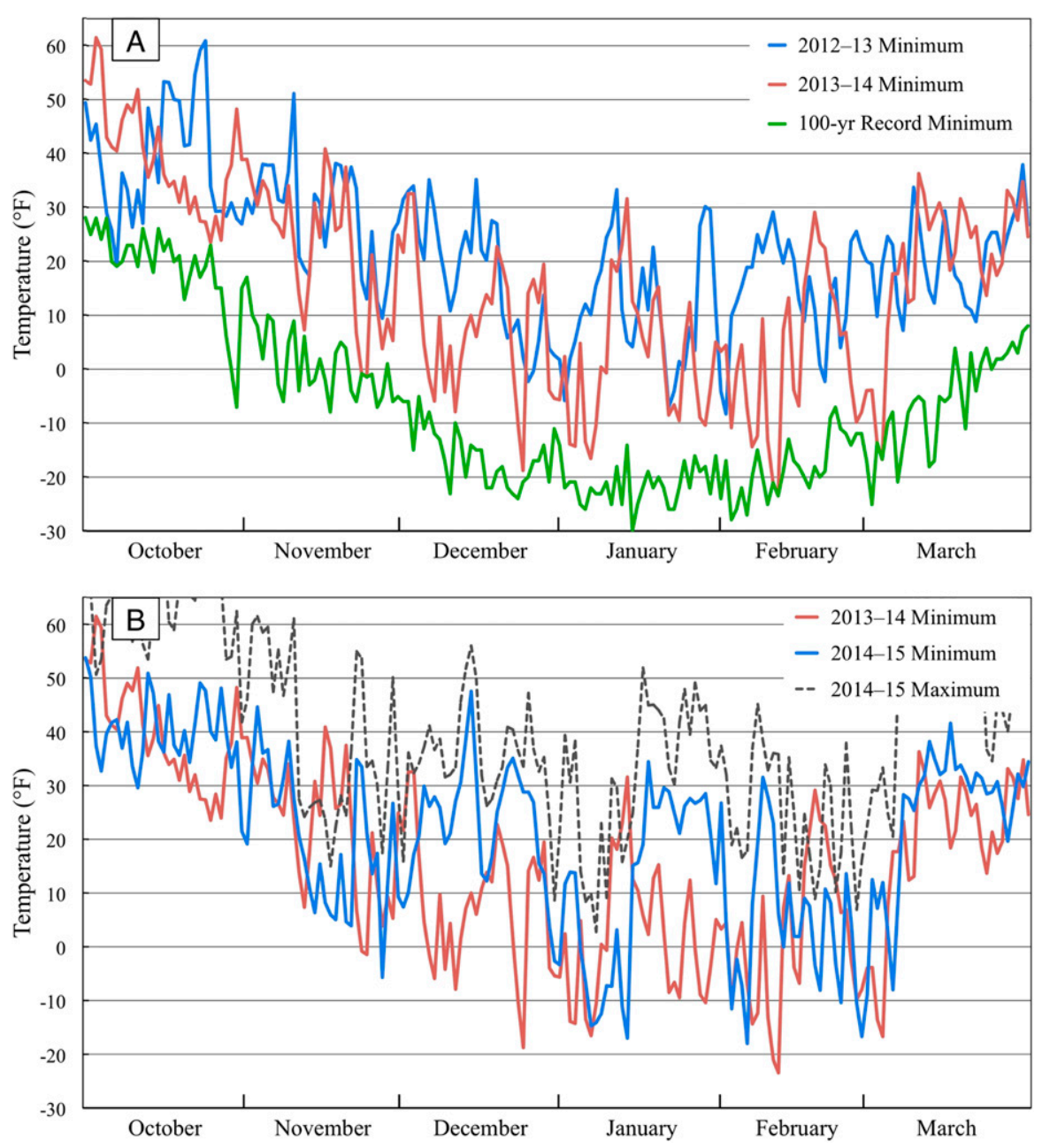

Fig. 1. Daily temperatures from 1 Oct. through 31 Mar. for the research farm in central Iowa (Gilbert, IA) where the trial of northern hybrid grape cultivars was conducted. (A) Minimum temperatures during Winter 2012-13 and 2013-14, and the 100-year record daily minimum. (B) Minimum temperatures during Winter 2013-14 and 2014-15, and maximum temperatures during Winter 2014$15 ;\left({ }^{\circ} \mathrm{F}-32\right) \div 1.8={ }^{\circ} \mathrm{C}$.

Survival of primary buds through the winter dormancy period is considered a key element for consistent productivity of wine grapes (Dami et al., 2005; Londo and Kovaleski, 2017). Even with compensatory pruning practices, most grape cultivars show reduced yield during seasons following substantial winter injury to primary buds, and the additional cost of compensatory pruning reduces profits (Dami et al., 2012; Martinson et al., 2014). The large variation in productivity following winter injury to primary buds underscores the importance of selecting cultivars that are sufficiently hardy for winter temperature extremes and fluctuations in the area where the grapes are to be grown (Londo and Kovaleski, 2017; Martinson et al., 2014; Minnesota Grape Growers Association, 2016). Cultivars that are
Seven of the cultivars (Frontenac, MN 1235, Marquette, La Crescent, MN 1258, MN 1220, and MN 1200) had consistently high bud survival $(>75 \%)$ during all six winters of the trial, which included two winters with record-breaking cold temperature events (Table 2, Fig. 1B). 'St. Croix' showed sufficient bud hardiness during five winters with average or mild temperatures but showed lower survival of primary buds $(57.2 \%$ and $63.1 \%$ ) during the 2 years that had extreme cold temperature events late in winter. Of the 12 northern hybrids that we evaluated, four of them ('Arandell', 'Corot noir', 'MN 1189', and 'Petit Ami') should be considered marginal for use in Iowa climate, with each showing at least 2 years of low primary bud survival of $6 \%$ to $41 \%$ during winters that had minimum temperatures colder than average (Table 2).

\section{Phenology in lowa climate}

Phenology of budbreak. A proper match between climate and the phenology of budbreak is perhaps the most crucial of the developmental stages in terms of its potential to cause crop reduction or failure. Even if primary buds have survived well through winter, a warm spring with a late hard freeze can kill emerging or actively growing shoots. If the freeze is severe, it can kill both the primary and secondary buds, causing substantial loss of fruit production for the season (Dami et al., 2005; Howell, 2003; Sabbatini and Tozzini, 2012). Our results for phenology of budbreak cover four consecutive years (2011-14), during which 50\% budbreak of northern hybrids in the trial occurred after the last hard freeze of spring for 3 of the 4 years (Table 4 ). In 2012, spring warming came much earlier than average, a weather event that had a negative effect on grape production across the midwestern United States because of freeze damage after vines had broken bud (Sabbatini and Tozzini, 2012). At our trial location in central Iowa, the average DOY in which 200 GDD accumulate is 118 . In 2012, our trial location accumulated 200 GDD by DOY $86,32 \mathrm{~d}$ earlier than average, and this early warming in combination with a damaging freeze $\left(21^{\circ} \mathrm{F}\right)$ on DOY 102 caused substantial injury to emerging and developing shoots (Domoto et al., 2013). 

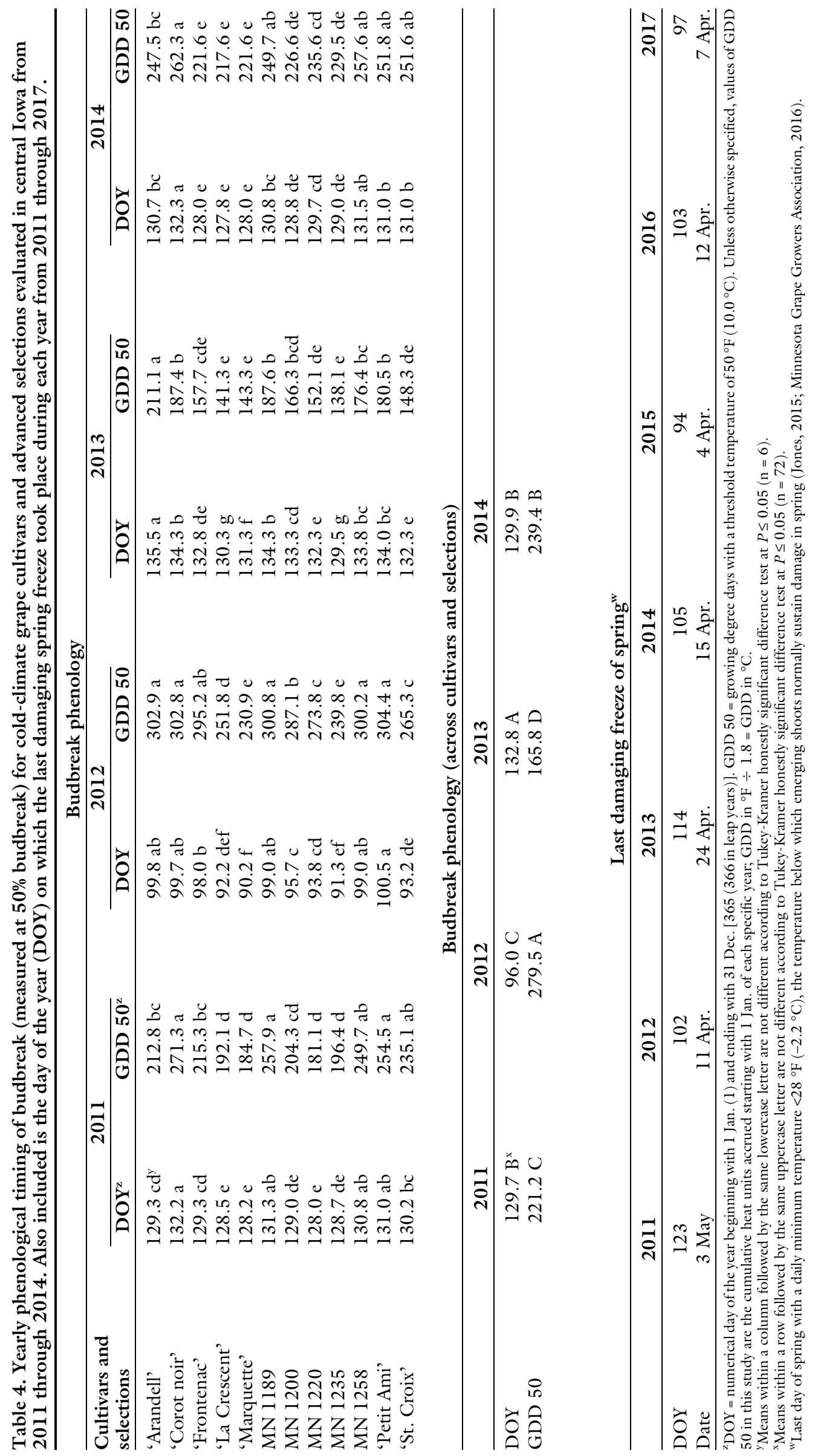
During the other 3 years of evaluation, spring warming was later than average, with accumulation of 200 GDD on DOY 129, 135, and 128 for 2011, 2013, and 2014, respectively. Spring freeze events were not a threat to bud or shoot survival during those 3 years. When including the timing of the last damaging freeze for the additional years calculated $(2015,2016$, and 2017), it seems likely that northern hybrids will have difficulty with spring freezes only when spring warming is earlier than average (Table 4 ).

The timing of spring warming had a strong effect on the timing of budbreak, but the effect was inconsistent across years for cultivars and for northern hybrids as a group. Even though sufficient chilling hours were received for the breaking of dormancy during each of the 4 years (Table 1 ), both the DOY and the GDD 50 showed significant differences across years (Table 4 ). The most noteworthy results were the low DOY and high GDD 50 recorded for budbreak in 2012 compared with the other 3 years (Table 4), results that were affected by the early spring warming that year. These results are inconsistent with the common theory that heat accumulation (GDD 50) is more accurate for predicting annual phenology than is calendar date (García de CortázarAtauri et al., 2009; Zapata et al., 2017). Common theory would expect that the DOY of budbreak would have been early during 2012 (which it was), but it also would expect that the GDD 50 should have been more consistent across the 4 years (which it was not). Differences in chilling hours do not resolve this inconsistency, because the chilling hours were greater for 2012 than they were for 2013 and 2014 (Table 1), therefore vines should have been prepared to break bud consistently with GDD in 2012, but did not. During the other 3 years $(2011,2013,2014)$, the variance in GDD 50 was greater than the variance in DOY for the northern hybrids as a group (budbreak across cultivars), further indicating the inconsistency of GDD 50 for predicting budbreak (Table 4). We conclude that GDD 50 is not a good predictor of budbreak in seasons with uncommon weather conditions, such as an early spring warming, and that it may not be much better than DOY for predicting budbreak of northern hybrids in Iowa climate.

Differences in budbreak phenology among cultivars were evident with both DOY and GDD 50 results (Table 4). Three of the cultivars (La Crescent, Marquette, and MN 1235) were among the earliest to break bud during all 4 years (Table 4 ), a characteristic that could indicate greater vulnerability of these cultivars to late spring freezing events. This conclusion is supported by the findings of Domoto et al. (2013), which showed substantial shoot damage to these cultivars, as well as to Corot noir and Arandell, during the freeze event in Spring 2012. Four cultivars (Corot noir, MN 1189, MN 1258, and Petit Ami) were among the latest to break bud during all 4 years (Table 4 ), suggesting that they could be less vulnerable than some cultivars to spring freeze events, but a general lack of cold tolerance for Corot noir indicates that it is vulnerable to spring freezes in Iowa even when exhibiting later budbreak than other cultivars (Domoto et al., 2013). The later budbreak of 'Petit Ami' is consistent with our conclusion based on correlations of winter bud survival (Table 3 ) that 'Petit Ami' is slower to deacclimate in late winter and spring than some cultivars. One of the cultivars (MN 1200) broke bud mid-range of the timing across cultivars during all 4 years, and four of the cultivars (Arandell, Frontenac, MN 1220, and St. Croix) broke bud early during some years and late during others (Table 4). For 'Frontenac', this variability in timing of budbreak compared with other cultivars may reflect a finer response to Iowa climate, because 2012 was one of the years that it broke bud later than many of the other cultivars (Table 4) and it showed strong shoot survival during the spring freeze event that year (Domoto et al., 2013). For 'St. Croix', the variability in budbreak phenology compared with other cultivars may increase its vulnerability in spring. In 2012, St. Croix broke bud earlier than many other cultivars ( $\mathrm{Ta}$ ble 4 ), making it more susceptible to freeze damage that year (Domoto et al., 2013). Although Arandell broke bud later than many other cultivars in 2012, its general lack of hardiness made it highly vulnerable to the spring freeze event that year (Domoto et al., 2013).
Phenology of bloom. The results for phenology of bloom $(50 \%$ bloom) were highly variable across years, particularly when considering the GDD 50 required for bloom during each of the 4 years (Table 5 ). As seen with budbreak phenology, early Spring 2012 caused the northern hybrids to bloom earlier than in other years, but the accumulated GDD 50 for bloom was much higher in 2012 than in the other 3 years (Table 5). This pattern was slightly different when looking at the phenology for the period between budbreak and bloom, with both the number of days and GDD 50 being greater in 2012 than during the other 3 years (Table 5). These results indicate that GDD 50 may be a poor predictor of bloom phenology, as well as budbreak phenology, during years with uncommon weather conditions such as an early spring warming, but they also illustrate that northern hybrid grapes base their timing of spring development on other environmental factors in addition to heat accumulation. Even though the early warming of 2012 caused both early budbreak and early bloom, the cultivars and northern hybrids as a group required more heat units (greater GDD 50) for both budbreak and bloom than they did during years that were nearer to average (Table 5). As discussed earlier, this cannot be attributed to delayed release from winter dormancy, because vines received more chilling hours preceding Spring 2012 than they did preceding Springs 2013 and 2014 (Table 1), and there were no warm periods during Winter 2011-12 that would have interrupted or reset the accumulation of chilling hours. Therefore, it is apparent that in 2012 vines adjusted their rate of development based largely on a factor (or factors) other than accumulated heat units. We hypothesize that daylength (photoperiod) may be more important in directing the annual phenology of northern hybrids (and possibly other grape species) than common theory suggests, but the importance of photoperiod is not easily observed except during years when heat accumulation and photoperiod are poorly correlated, as was experienced in Spring 2012. The influence of photoperiod as an environmental cue in directing seasonal phenology is supported by basic 


\section{Research Reports}

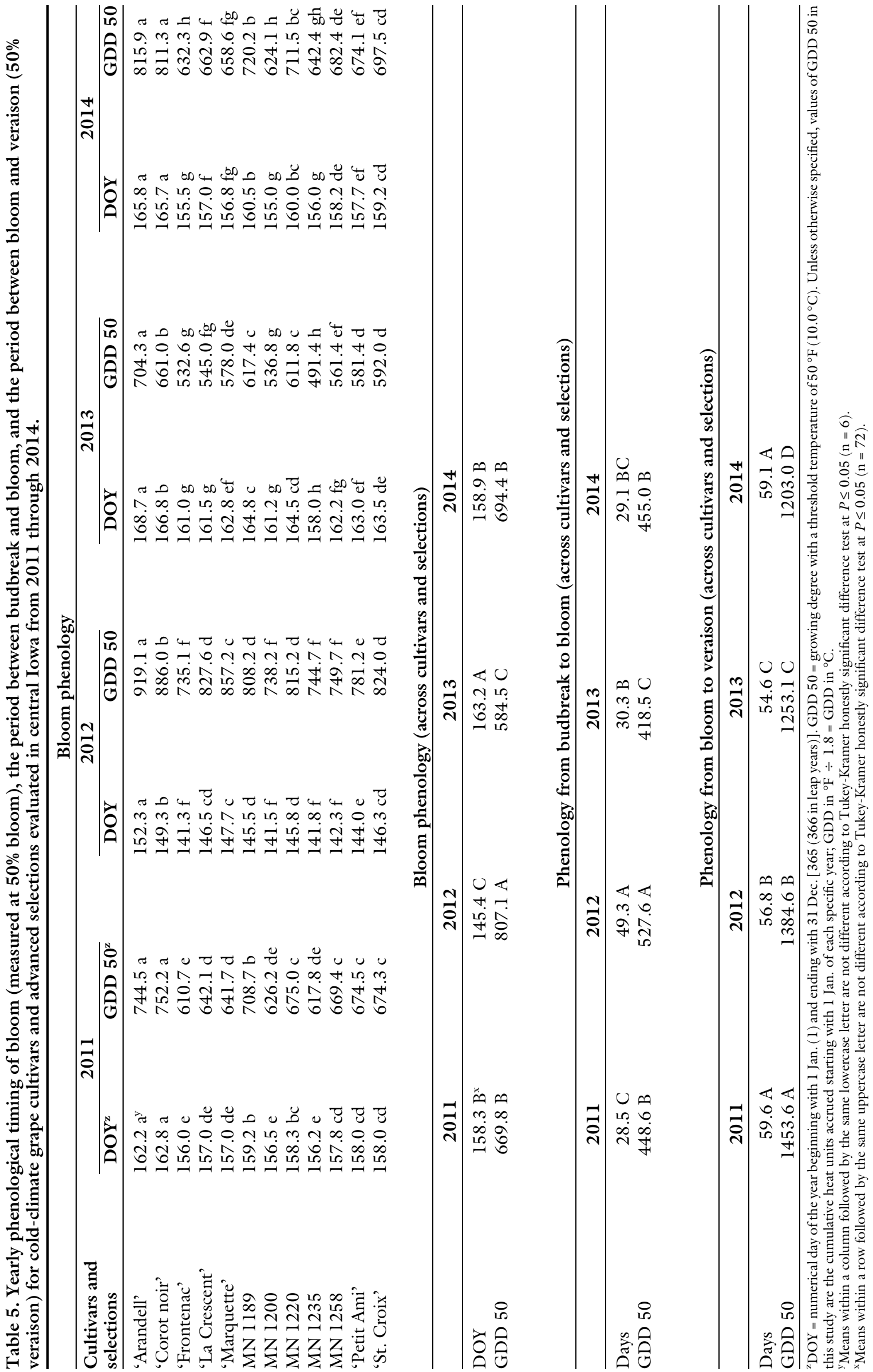


research with woody plants, but the importance of photoperiod in guiding phenology varies by species (Schaber and Badeck, 2003; Way and Montgomery, 2015). The Huglin index, a bioclimatic index for grape phenology, incorporates a basic photoperiod coefficient adjusted by geographical latitude, but this photoperiod component is an adjustment based on potential for solar radiation (Bonnefoy, 2017; Gu, 2016; Huglin, 1978), rather than representing photoperiod as a cue that vines use to help guide the timing of annual phenology. Our results suggest that photoperiod (and perhaps other factors), in addition to heat accumulation, has a strong influence on phenological timing during years with unusual temperature patterns.

During each season, budbreak and early growth need to be late enough for cultivars to avoid injury from spring freezes, but after the threat of freeze damage is over, development must proceed quickly enough for fruit to reach maturity (harvest) before the arrival of cold autumn temperatures that can impede fruit ripening or cause freeze damage to fruit (Dami et al., 2005; Minnesota Grape Growers Association, 2016). In our trial, there were differences in the phenology of bloom among cultivars, and there was variation across years in the phenology of some cultivars relative to that of others (Table 5). 'Arandell' and 'Corot noir' were among the latest to bloom during all 4 years of evaluation, and four other cultivars (Frontenac, La Crescent, MN 1200, and $\mathrm{MN} 1235$ ) were among the earliest to bloom during each of the 4 years (Table 5 ). There were no results for bloom phenology that suggest vulnerabilities for any of the cultivars, but there were noteworthy outcomes that became discernible by comparing the phenology of budbreak to the phenology of bloom. Although 'Frontenac' was among the latest to break bud during early Spring 2012, a characteristic that made it less vulnerable during the damaging spring freeze that year, it was one of the earliest to bloom that year and during the other 3 years (Tables 4 and 5 ). We present this as further evidence that 'Frontenac' is very well suited for the variable climate of the midwestern United States, and its finer control of phenology despite rapid accumulation of heat units (GDD 50) in 2012 suggests that daylength and/ or other factors may be more important in guiding the phenology of Frontenac than it is for some of the other cultivars. Two cultivars (MN 1258 and Petit Ami) broke bud later and bloomed earlier than other cultivars during all 4 years of evaluations (Tables 4 and 5), a characteristic that could make them well suited for midwestern U.S. climates that have short growing seasons and often have late spring freezes.

Phenology of veraison AND HARVEST. Phenology of veraison varied across cultivars and across years. For the northern hybrids as a group (yearly means across cultivars), 50\% veraison was earliest in 2012 (the year with an unusually early spring), but the GDD 50 required for veraison that year was greater than during the other 6 years (Table 6). There was also more variance for GDD 50 among years than for DOY. Veraison of the northern hybrids was later in 2013 and 2014 than it was in 2012 , 2016, and 2017, but the GDD 50 required for veraison in 2013 and 2014 was much lower than during the other 5 years (Table 6 ). The GDD 50 units accumulated during the period between bloom and veraison was also less consistent across years than was the number of days required for that stage of development (Table 5). Therefore, as seen with budbreak and bloom, GDD 50 also appears to be a poor predictor for veraison phenology of northern hybrids in Iowa climate.

The phenology of fruit maturity (harvest) by year showed a similar trend to that of veraison; however, the DOY for harvest of northern hybrids as a group was not different for 2012 and 2016, years that had the earliest harvest dates of the 7 years (Table 6). Although the harvest dates were not different for 2012 and 2016, the GDD 50 results for these years were substantially different, with GDD 50 being much greater in 2012 than it was in $2016(3045.6$ and 2757.1, respectively). This dissimilarity between the phenology of veraison and harvest can be explained by results for the period between veraison and harvest, which took 5 $\mathrm{d}$ fewer in 2016 than in 2012 and also required fewer GDD 50 units in 2016 than in 2012 (Table 6). Based on the yearly DOY results for harvest phenology compared with yearly DOY for the first damaging freeze of autumn, northern hybrid grapes are much less vulnerable to cold temperature damage in the fall than they are in the spring (Table 6). Although the northern hybrids in our trial broke bud earlier than the last damaging freeze of spring during 1 year (Table $4)$, they reached harvest maturity well before the first damaging freeze of autumn during every year (Table 6). In addition, the latest DOY for harvest was 272 in 2011 (cultivars MN 1235 and MN 1258), and the earliest damaging freeze was DOY 280 in 2012. Therefore, we conclude that none of the cultivars in our trial are vulnerable to autumn freeze damage to fruit in Iowa's climate; however, this does not infer that late season temperatures have no impact on yield or fruit quality.

The phenological results for veraison and harvest were more consistent for cultivars across years than were the results for budbreak and bloom, and there were no important interactions of years and cultivars for these two parameters. Therefore, our results for veraison and harvest were summarized for each cultivar as means across the 7 years of evaluation (2011-17) rather than for each year (Table 6). On average, 'Arandell' and 'Corot noir' were the last of the cultivars to reach $50 \%$ veraison, and three of the cultivars (Marquette, $\mathrm{MN}$ 1189, and MN 1200) reached veraison earlier than the others and with significantly lower accumulated GDD 50 (Table 6). For the rest of the cultivars, there were no differences in phenology of veraison for either DOY or GDD 50. The results for harvest did not follow the same trend as results for veraison, and there were substantial differences among cultivars for the period between veraison and harvest. Two of the cultivars (Frontenac and MN 1235) were among the latest to reach harvest maturity and they required more GDD 50 units for harvest than most of the other cultivars (Table 6). The number of days and GDD 50 units for the period between veraison and harvest were also greater for these two cultivars than for most of the others. The average period between veraison and harvest was especially long for 


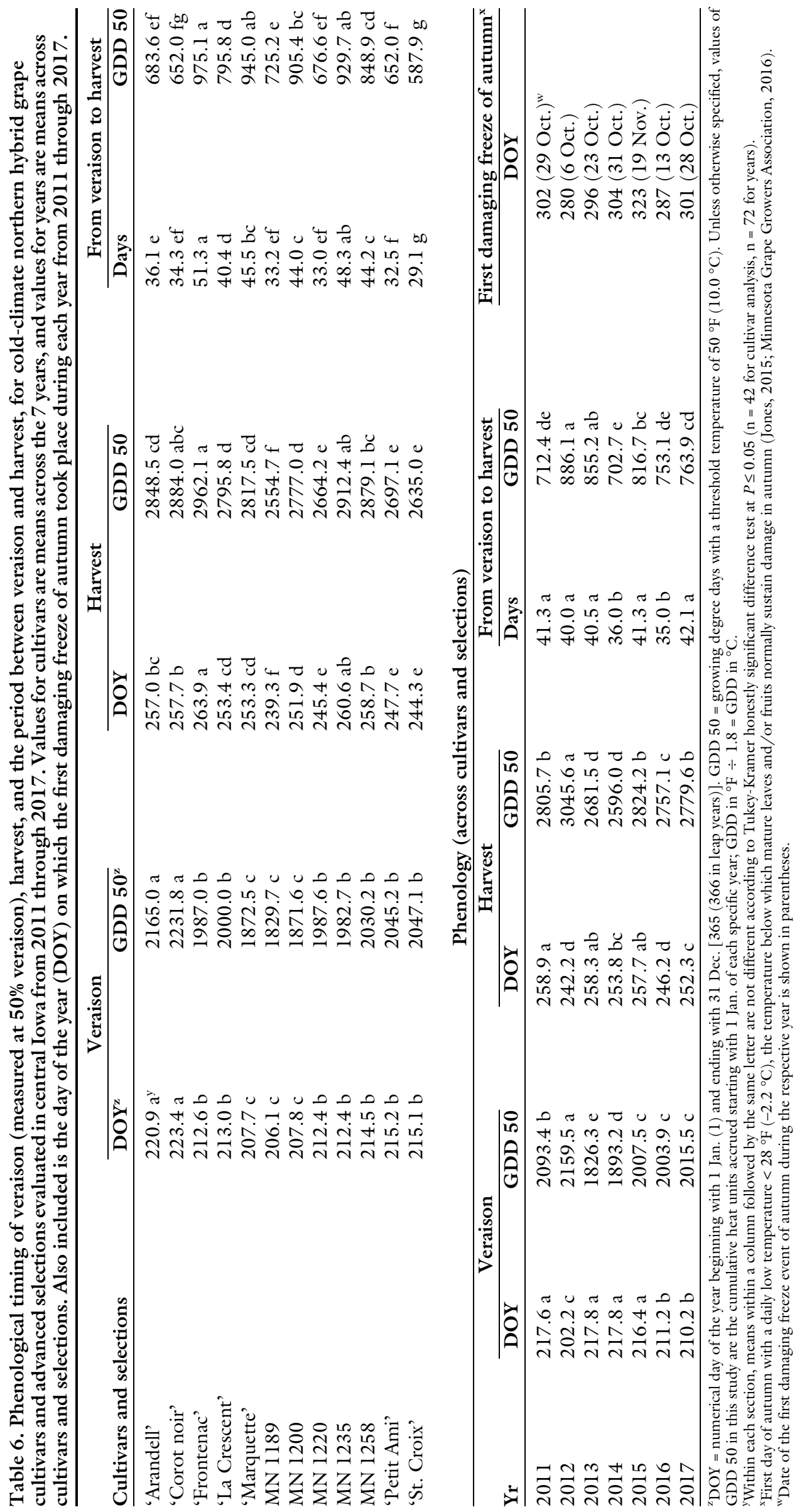









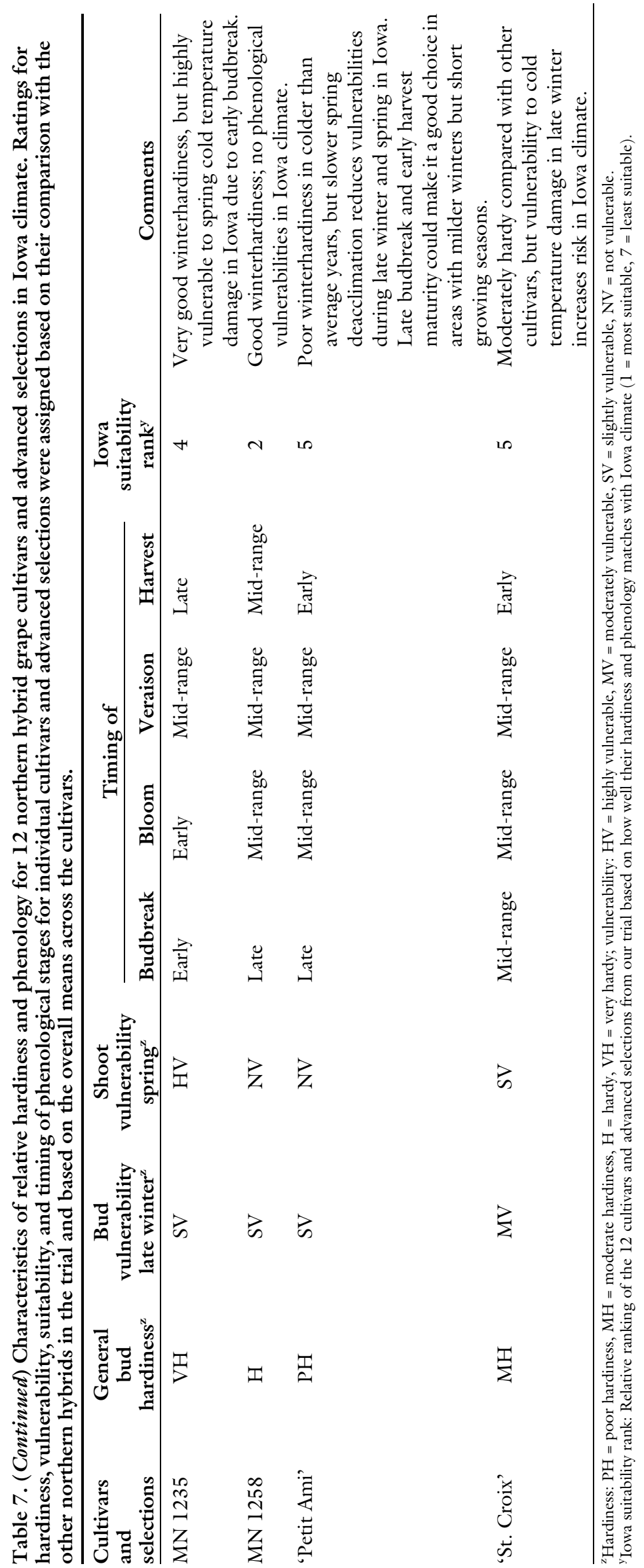

'Frontenac' (51.3 d and 975.1 GDD), a result that provides more evidence to support the notion that 'Frontenac' is more responsive to photoperiod and/or some other environmental cue in directing its phenology and is less responsive to accumulated heat units than are other cultivars. Even with its later average harvest date, 'Frontenac' is not vulnerable to freeze damage of fruit in Iowa climate. Its average harvest date (DOY 263.9) and its latest harvest date (DOY 269 in 2013) were well ahead of the earliest damaging freeze of autumn recorded during the trial (DOY 280 in 2012). The cultivars with the earliest average harvest maturity were MN 1189, MN 1220, Petite Ami, and St. Croix (Table 6). Although none of the cultivars in our trial were vulnerable to autumn freeze damage of fruit in Iowa climate, these earlier ripening cultivars may be good choices for areas with shorter growing seasons than Iowa, particularly if the area also has a warmer winter and a lower threat of late spring freezes.

AsSESSMENT OF GDD 50 INDEX. Along with the use of heat unit summation for comparing growing regions, cultivars, and/or growing seasons, it is often suggested that tracking of heat units during a season can be a useful way to predict the arrival of important developmental stages for grapes and other fruit crops, and GDD 50 is most often the index of choice for calculating heat units for grapes (García de Cortázar-Atauri et al., 2009; Gentilucci and Burt, 2018; Verdugo-Vásquez et al., 2017; Washington State University, 2016; Zapata et al., 2017). Our results with northern hybrid grapes over seven growing seasons indicate that GDD 50 is useful for comparing seasons and cultivars, but its accuracy as a stand-alone index for predicting annual phenology in midwestern U.S. climates is poor. In our trial, there were large variations in GDD 50 requirements across years for all four phenological stages (budbreak, bloom, veraison, and harvest), and the use of GDD summation for predicting phenology during years of unusual weather conditions was especially problematic. A clear example of the inaccuracy of GDD 50 for estimating phenology of the northern hybrids can be seen in our results for 
2012 , the year of our trial that had an early spring. During 2012, results for northern hybrids as a group showed that budbreak occurred $26.1 \mathrm{~d}$ earlier than average $(23.9 \%$ different from average DOY) and the GDD 50 required for budbreak was 53.0 units greater than average $(21.0 \%$ different from average GDD), indicating that GDD 50 was only slightly better for estimating budbreak than was the simple calendar date (DOY). For the phenology of harvest maturity that year, DOY for harvest was $10.6 \mathrm{~d}$ earlier than average $(4.3 \%$ different from average DOY) and GDD 50 required for harvest was 261.4 units greater than average $(9.0 \%$ different from average GDD). Although the accuracy of both indices improved proportionally (smaller percentage difference from average) by the time cultivars reached harvest maturity, at this stage, calendar date (DOY) was more accurate for estimating phenology than was GDD 50. Based on our results, we conclude that heat summation (and specifically GDD 50) has limited usefulness as a stand-alone index for predicting the annual phenology of northern hybrids in midwestern U.S. climates, and its usefulness is particularly problematic in years with atypical weather patterns. It is also apparent that use of the Huglin index would not provide a significant improvement, because the photoperiod multiplier of the Huglin index is based on location only, and therefore would be the same for all years of the trial (Bonnefoy, 2017; Gu, 2016; Huglin, 1978). We hypothesize that a more accurate index for predicting annual phenology of midwestern U.S. grapes could be developed by including additional environmental parameters, such as photoperiod, solar radiation accumulation, and/or soil temperature that could be collected and quantified simultaneously with GDD units each season.

\section{Suitability of cultivars for lowa climate}

Of the grape cultivars currently available, northern hybrids provide the greatest probability for consistent, successful production in the challenging climates of Iowa and other areas in the upper midwestern United States (Minnesota Grape Growers Association, 2016; Smiley et al., 2016). Along with the potential to provide high-quality fruit, cultivars suitable for use in Iowa and similar areas must be hardy enough to withstand cold, variable winters, and their phenology must match well enough with the short and often inconsistent growing seasons for vines to produce an acceptable crop year after year. We used the results from our 7-year evaluation to characterize the suitability of the 12 northern hybrid cultivars in Iowa climate. An itemized summary of the relative hardiness, vulnerabilities, and timing of phenological stages of these cultivars is provided in Table 7. Based on hardiness and phenology, four of these cultivars (Frontenac, $\mathrm{MN} 1258, \mathrm{MN} 1220$, and $\mathrm{MN}$ 1200 ) provide the greatest probability for consistent production in Iowa and the lowest risk of issues related to cold temperatures (Table 7). Three other cultivars (La Crescent, Marquette, and MN 1235) have good potential for consistent production but are more vulnerable to cold temperature damage in late winter and/or spring. Two of the cultivars (Petit Ami and St. Croix) should be considered marginal for use in colder areas of Iowa but may perform well in warmer locations in Iowa or during years with average or warmer winter and spring conditions. Our results indicate that 'Arandell', 'Corot noir', and 'MN 1189' are not appropriate for Iowa climate due to poor bud hardiness and vulnerability to cold temperature damage in late winter and early spring (Table 7 ).

\section{Literature cited}

Andresen, J., S. Hilberg, and K. Kunkel. 2012. Historical climate and climate trends in the Midwestern USA. In: J. Winkler, J. Andresen, J. Hatfield, D. Bidwell, and D. Brown, coordinators. Great Lakes Integrated Sciences and Assessments Center. U.S. Natl. Climate Assessment Midwest Tech. Input Rpt. 17 Apr. 2019. <http://glisa.umich.edu/ media/files/NCA/MTIT_Historical. pdfs.

Antivilo, F.G., R.C. Paz, M. Echeverria, M. Keller, J. Tognetti, R. Borgo, and F.R. Juñent. 2018. Thermal history parameters drive changes in physiology and cold hardiness of young grapevine plants during winter. Agr. For. Meteorol. 262:227236.

Bonnefoy, C. 2017. Bioclimatic indices of the ripening period: The Huglin index. 9 Apr. 2019. <https://blog.vintagereport. com/en/2017/09/18/ bioclimaticindices-ripening-period-huglin-index/> .

Bordelon, B. 2001. Grape varieties for Indiana. Purdue Univ. Coop. Ext. Serv. Publ. HO-221-W.

Bradshaw, T.L., L.P. Berkett, S.L. Kingsley-Richards, and J.A. Foster. 2018. Horticultural performance and juice quality of cold-climate grapes in Vermont, U.S.A. Eur. J. Hort. Sci. 83:42-48.

Current Results Publishing. 2019a. Summer temperature averages for every state. 5 Mar. 2019. <www.currentresults.com/ Weather/US/average-state-temperaturesin-summer.php>.

Current Results Publishing. 2019b. Winter temperature averages for every state. $5 \mathrm{Mar}$. 2019. <www.currentresults.com/ Weather/US/average-state-temperaturesin-winter.php>.

Dami, I., B. Bordelon, D.C. Ferree, M. Brown, M.A. Ellis, R.N. Williams, and D. Deehan. 2005. Midwest grape production guide. Ohio State Univ. Ext. Bul. 919.

Dami, I.E., S. Ennahli, and Y. Zhang. 2012. Assessment of winter injury in grape cultivars and pruning strategies following a freezing stress event. Amer. J. Enol. Viticult. 63:106-111.

Dharmadhikari, M.R. and K.L. Wilker. 2001. Micro vinification: A practical guide to small scale wine production. Midwest Viticult. Enol. Ctr., Southwest Missouri State Univ., Mountain Grove, MO.

Dokoozlian, N.K. 1999. Chilling temperature and duration interact on the budbreak of 'Perlette' grapevine cuttings. HortScience 34:1054-1056.

Domoto, P. 2014. Pruning grape vines Evaluating and adjusting for cold injury. Iowa State Univ. Ext. Wine Growers News \#261.

Domoto, P.A., G.R. Nonnecke, P. Tabor, and L.B. Riesselman. 2013. Cold hardy wine grape cultivar trial. Iowa State Res. Farm Prog. Rpt. 1915.

Dry, P. and B. Coombe. 2004. Grapevine growth stages - The modified E-L system. Viticulture 1 - Resources. 2nd ed. Winetitles Media, Broadview, Australia.

Eichhorn, K.W. and D.H. Lorenz. 1977. Phönologische entwicklungsstadien der rebe. Nachrichtenblatt des Deutschen Pflanzenschutzdienstes Braunschweig 29:119-120.

García de Cortázar-Atauri, I., N. Brisson, and J.P. Gaudillere. 2009. Performance of several models for predicting budburst date of grapevine (Vitis vinifera L.). Intl. J. Biometeorol. 53:317-326. 
Gentilucci, M. and P. Burt. 2018. Using temperature to predict the end of flowering in the common grape (Vitis vinifera) in the Macerata wine region, Italy. EuroMediterranean J. Environ. Int. 3:38, doi: 10.1007/s41207-018-0079-4.

Goffinet, M.C. 2004. Anatomy of grapevine winter injury and recovery. Dept. Res. Paper, Dept. Hort. Serv., Cornell Univ., Geneva, NY.

Gu, S. 2016. Growing degree hours - A simple, accurate, and precise protocol to approximate growing heat summation for grapevines. Intl. J. Biometeorol. 60: 1123-1134.

Hatterman-Valenti, H.M., C.P. Auwarter, and J.E. Stenger. 2016. Evaluation of coldhardy grape cultivars for North Dakota and the North Dakota State University germplasm enhancement project. Acta Hort. 1115:13-22.

Howell, G.S. 2003. Factors related to spring frost damage: What are the options. 22 Mar. 2019. <www.canr.msu. edu/grapes/uploads/files/factorsrelated.pdf>.

Huglin, P. 1978. Nouveau mode d'eìvaluation des possibiliteìs heiliothermiques d'un milieu viticole. C. R. Acad. Agr. Fr. 64:1117-1126.

Iland, P. 2004. Chemical analysis of grapes and wine: Techniques and concepts. Patrick Iland Wine Promotions, Adelaide, Australia.

Iowa State University. 2019. Iowa Environmental Mesonet. 28 May 2019. <https://mesonet.agron.iastate.edu/>.

Jones, G.V. 2015. Climate, grapes, and wine: Terroir and the importance of climate to winegrape production. GuildSomm, Petaluma, CA.

Livingstone, D.J. 2009. A practical guide to scientific data analysis. Wiley, Hoboken, NJ.

Londo, J.P. and L.M. Johnson. 2014. Variation in the chilling requirement and bud burst rate of wild Vitis species. Environ. Expt. Bot. 160:138-147.
Londo, J.P. and A.P. Kovaleski. 2017. Characterization of wild North American grapevine cold hardiness using differential thermal analysis. Amer. J. Enol. Viticult. 68:203-212.

Martinson, T., H. Walter-Peterson, L. Haggerty, and J. O'Connell. 2014. How well did winter bud injury measurements predict the final grape crop? Cornell Univ., Appellation Cornell \#19. 2 May 2019. <https://grapesandwine.cals. cornell.edu/newsletters/appellationcornell/2014-newsletters/issue-19. december-2014/>.

Minnesota Grape Growers Association. 2016. Growing grapes in Minnesota. 10th ed. (revised by P. Domoto, C. Anderson, M. Clark, and I. Geary). 26 Mar. 2019. <https://c.ymcdn.com/ sites/mngrapegrowers.site-ym.com/ resource/resmgr/Growing_Grapes_in_ MN_Best_Practices/GGIM_Best_ Practices-book.pdf>.

Moyer, M., L. Mills, G. Hoheisel, and M. Keller. 2011. Assessing and managing cold damage in Washington vineyards. Washington State Univ. Ext. Publ. EM043E.

Reisch, B.I. and S. Luce. 2005. The less risky varieties, old and new. 20 Mar. 2019. <http://www.hort.cornell.edu/ reisch/grapegenetics/ winehandout. html>.

Reisch, B.I., R.M. Pool, D.V. Peterson, M.H. Martens, and T. Henick-Kling. 2002. Wine and juice grape varieties for cool climates. Cornell Univ. Coop. Ext. Bul. 233.

Sabbatini, P. and L. Tozzini. 2012. The effects early spring had on Michigan juice grapes. 9 July 2019. <https://www.canr. msu.edu/news/the_effects_early_ spring_had_on_michigan_juice_grapes $>$.

Sahu, P.K. 2013. Research methodology: A guide for researchers in agricultural science, social science and other related fields. Springer, New York, NY.

Schaber, J. and F.W. Badeck. 2003. Physiology-based phenology models for forest tree species in Germany. Intl. J. Biometeorol. 47:193-201.

Schrader, J.A. and W.R. Graves. 2003. Phenology and depth of cold acclimation in the three subspecies of Alnus maritima. J. Amer. Soc. Hort. Sci. 128:330336.

Smiley, L.A., D. Cochran, P. Domoto, G. Nonnecke, and W.W. Miller. 2016. A review of cold climate grape cultivars. Iowa State Univ. Ext. Publ. Hort 3040.

U.S. Department of Agriculture. 2019. USDA plant hardiness zone map. 9 July 2019. <https://planthardiness.ars.usda. gov/PHZMWeb/InteractiveMap.aspx>.

Verdugo-Vásquez, N., C. Pañitrur-De la Fuente, and S. Ortega-Farías. 2017. Model development to predict phenological scale of table grapes (cvs. Thompson, Crimson and Superior Seedless and Red Globe) using growing degree days. OENO One. 14 May 2019. <https:// oeno-one.eu/article/view/1833>.

Washington State University. 2016. Growing degree days. 29 Mar. 2019. <http://wine.wsu.edu/extension/ weather/growing-degree-days/>.

Way, D.A. and R.A. Montgomery. 2015. Photoperiod constraints on tree phenology, performance and migration in a warming world. Plant Cell Environ. 38:1725-1736.

Weaver, K.F., V. Morales, S.L. Dunn, K. Godde, and P.F. Weaver. 2017. An introduction to statistical analysis in research: With applications in the biological and life sciences. Wiley, Hoboken, NJ.

Zapata, D., M. Salazar-Gutierrez, B. Chaves, M. Keller, and G. Hoogenboom. 2017. Predicting key phenological stages for 17 grapevine cultivars (Vitis vinifera L.). Amer. J. Enol. Viticult. 68:60-72. 